\title{
JNVEST]GAÁAJÓN
}

\section{Antioxidant and antimicrobial effects of some natural plant extracts added to lamb patties during storage}

\author{
By Hayam M. Ibrahim, ${ }^{*}$ Azza A. Abou-Arab and Ferial M. Abu Salem \\ Food Technology Dept., National Research Center, Dokki, Cairo, Egypt \\ ( ${ }^{*}$ Corresponding author: hm_ibrahim2002@yahoo.com)
}

\section{RESUMEN}

Efecto antioxidante y antimicrobiano de algunos extractos de plantas naturales añadidos a pastel de cordero durante el almacenamiento.

Las plantas naturales están consideradas como un importante producto donde buscar y encontrar nuevas fuentes de antioxidantes naturales y/o agentes antimicrobianos. La concentración óptima de algunos extractos de plantas naturales (jojoba, jatropha, ginseng y jengibre) fueron determinado y añadidas a pasteles de cordero. Algunas características químicas y microbiológicas de los pasteles preparados y almacenados durante 9 días a $4^{\circ} \mathrm{C}$ fueron evaluados. Tanto la adición de estos extractos como el tiempo de almacenamiento tuvieron un efecto significativo en los pasteles en el periodo de almacenamiento. La efectividad de los extractos naturales ensayados puede ser enumerada en el siguiente orden decreciente de valores de substancias reactivas con el ácido tiobarbitúrico (TBARS): ginseng $>$ jatropha $>$ jojoba $>$ jengibre. El recuento de microorganismos decreció significativamente con la adición de los extractos durante el periodo de almacenamiento. Comparado con los pasteles control, la adición de estos extractos naturales fue efectiva como agente antioxidante y antimicrobiano en la mejora de las propiedades de los pasteles de cordero.

PALABRAS-CLAVE: Aminas biogénicas - Antimicrobiano - Antioxidante -Extracto de plantas naturales - Oxidación lipídica - Pastel de cordero - Recuento microbiano.

\section{SUMMARY}

Antioxidant and antimicrobial effect of some natural plant extracts added to lamb patties during storage.

Natural plants are considered an important target to investigate in order to provide a new source of natural antioxidants and/or antimicrobial agents. The optimum concentrations of some natural plant (jojoba, jatropha, ginseng and ginger) extracts were determined and added to lamb patties. Some chemical and microbial characteristics of the prepared patties during storage for 9 days at $4^{\circ} \mathrm{C}$ were evaluated. Both the addition of these extracts and storage time had a significant effect on the patties throughout the storage period. The effectiveness of the tested natural extracts can be listed in the following order of decreasing Thiobarbituric acid reactive substance (TBARS) values: ginseng $>$ jatropha $>$ jojoba $>$ ginger. Aerobic plate count, mould and yeast counts decreased significantly with addition of the extracts during the storage period. Also, the addition of the extracts was significantly effective in reducing histamine, tyramine and putrescine formation during the storage period. Compared to control patties, the addition of these natural extracts was effective as antioxidant and antimicrobial agents for improving the properties of lamb patties.

KEY-WORDS: Antimicrobial - Antioxidant - Biogenic amines - Lamb patties - Lipid oxidation - Microbial counts Natural plant extracts.

\section{INTRODUCTION}

Lipid oxidation and the growth of undesirable microorganisms in food products results in the development of spoilage, off flavor, rancidity, and deterioration, rendering such products unacceptable for human consumption (Bozin et al., 2007) and yielding many compounds that contribute to the pathogenesis of cancer, atherosclerosis, heart and allergic diseases (Mielnik et al., 2008; Tang et al., 2001).

The presence of biogenic amines in food constitutes a potential public health concern due to their physiological and toxicological effects. It is important to monitor biogenic amine levels in fresh and processed food not only due to their toxicity but also because they can be a useful index of spoilage (Önal, 2007).

Lipid oxidation and microbial growth in meat products may be controlled or at least minimized by using either synthetic or natural food additives commonly used in the meat industry (Gray et al., 1996; Lee et al., 1997; Mielnik et al., 2003; Sallam et al., 2004; Estevez and Cava, 2006).

The natural antioxidants found in plants have gained considerable interest for their role in preventing the auto-oxidation of fats, oils and fat containing food products (Reddy et al., 2005). The antioxidant properties of herbs, spices, plant and other food extracts are apparently related to their phenolic content, suggesting that antioxidant action is similar to that of synthetic phenolic antioxidants (Lai et al., 1991). 
Since the worldwide trend towards the use of natural additives in food (Yanishlieva et al., 2006); natural plants are considered an important target to investigate in order to provide a new source of natural antioxidants and/or antimicrobial agents from a safety view point. Consequently, there is a practical need for the screening and selection of natural antioxidants as effective alternatives in the prevention of food deterioration (Kikuzaki and Nakatani, 1993). Several plants with very high nutritive values exist and yet remain unexploited for human and animal benefits (Oladele and Oshodi, 2007). Therefore, the search for, and development of other antioxidants and antimicrobials of natural origin are highly desirable.

Jatropha curcas is a nut belonging to the Euphobiaceae family. Recently, the tree of this plant has been successfully cultivated in Upper Egypt (Hawash et al., 2009) and all parts of it have specific uses as determined by Gubitz et al., (1999) and Makkar et al., (1997). El Diwani et al., (2009) reported that the residue of the methanolic extract of Egyptian jatropha curcas contains bioactive substances such phenolic compounds, which were successful as natural antioxidants against oxidative deterioration.

The flavonoid profile of the fruits of the Jojoba plant, Simmondsia chinensis may place this family among other families which are rich in flavonol methyl ethers and flavonoid content which make the pericarp a valuable source for antioxidant and hepato-protective compounds (El-Halwany, 2002). This plant extract has been reported to be useful as a dietary supplement for use in a weight control regiment in humans, a component of functional food, a food additive, a medical food, or as a therapeutic agent (Teague et al., 2005).

Ginseng is an herbaceous perennial belonging to the Aralia family. It is used early for medicinal purposes and used widely in herbal, health food and cosmetic applications (Rangahau, 2001). Various formulations prepared from the Panax ginseng root have been marketed as dietary supplements, especially in China where it is frequently used as a food additive and as raw materials of healthy food rather than therapeutic agents (Gillis, 1997; Shen et al., 2003). Bioactive compounds from medicinal plants including ginseng are known to protect against oxidative stress from reactive oxygen species and prevent lipid per-oxidation (Sievenpiper et al., 2003; Fuzzati, 2004).

The rhizome of the popular ginger species, Zinger officinale, is widely used as a spice and food seasoning due to its sweet aroma and pungent taste. It is well known to have antioxidant activity (Jitoe et al., 1992; Zia-ur-Rehman et al., 2003,) and effective antimicrobial agents. A ginger rhizome extract exhibited the highest antioxidant activity (Mansour and Khalil. 2000) due to the effect of its total phenols (Stoilova et al., 2007).

The interest in the antioxidant activity of plant extracts has become greater and very important (Joyeux et al., 1995; Azaizeh et al., 2005; Alma et al., 2003) due to the fact that free radicals e.g. reactive oxygen species (ROS) can be responsible for various diseases, e.g. heart diseases, stroke, arteriosclerosis and cancer, as well as being involved in the aging process (Willcox et al., 2004). The effects of plant extracts or essential oils classified as greatly recognized as safe (GRAS) following their addition, have been studied extensively and reported in a variety of meat types, including pork (Nissen et al., 2004); beef (Solomakos et al., 2008); lamb (Camo et al., 2008).

Lamb meat contains higher levels of $\omega \dot{\omega}-3$ polyunsaturated fatty acids (PUFAs) compared to beef or pork, which is beneficial to human health (Wood et al., 1999); however, PUFAs increase the susceptibility of meat to oxidative processes such as lipid oxidation ultimately leading to off odors and warmed over flavor (Jeremiah, 2001).

The objectives of the present study were: i) To establish the optimum concentrations of some natural plant extracts: jojoba (Jo), jatropha (Ja), ginseng $(\mathrm{Gg})$ and ginger $(\mathrm{Gr})$ as sources of natural antioxidants and/or antimicrobial agents to be added to lamb patties in order to diminish oxidative and microbiological deterioration. ii) To evaluate the effects of the natural extracts at the optimum concentrations on the evolution of quality parameters (thiobarbituric acid reactive substances (TBARS), biogenic amines (BA), microbiological count) in the prepared lamb patties stored at $4^{\circ} \mathrm{C}$ for 9 days.

\section{MATERIALS AND METHODS}

\subsection{Materials}

Four natural plants (Jojoba Simmondsia chinensis, jatropha curcas, Panax ginseng and ginger, Zinger officinale) were used as sources of antioxidants and antimicrobial agents. Jojoba (pericarp) was purchased from the Egyptian Natural Oils Company, Cairo, Egypt. Jatropha curcas (leaves and roots) were obtained from the Ministry of Agriculture and Reclamation Land., Egypt. Jojoba and Jatropha were air-dried, powdered and kept in tightly closed amber glass containers. Ginger rhizomes (Zingiber officinal) were purchased from the local market. a ginseng extract was obtained from the Korean Society of ginseng, Seaul, Korea as a gift. Thiobarbituric acid (TBA), 1,1,3,3tetraethoxypropan (TEP) and other chemicals used were of analytical grade and obtained from Sigma Chemical Co (St. Louis, MO).

\subsection{Preparation of the plant extracts}

\section{Jojoba extract}

Air-dried powdered pericarp (one $\mathrm{kg}$ ) of jojoba was exhaustively defatted using hexane and then extracted with ethanol $70 \%$ by percolation. The ethanolic extract was combined and evaporated under reduced pressure to yield $50 \mathrm{gm}$ of dry residue. 
The residue was suspended in water $(250 \mathrm{ml})$ and partitioned successively with chloroform $(5 \times 50 \mathrm{ml})$ followed by ethyl acetate $(5 \times 50 \mathrm{ml})$ and $n$-butanol $(7 \times 50 \mathrm{ml})$. The solvents were evaporated under reduced pressure to give chloroform fraction (11gm), ethyl acetate fraction $(4 \mathrm{gm})$ and butanol fraction (10gm) (El-Halwany, 2002).

\section{Jatropha extract}

Ten grams of the air-dried powder of the leaves and roots of jatropha were extracted successively under shaking with chloroform $\left(\mathrm{CHCl}_{3}\right)$ three to five times at room temperature, with $90 \%$ methanol $\left(\mathrm{CH}_{3} \mathrm{OH}\right)$ in a water-bath at $50^{\circ} \mathrm{C}$ three to five times and finely with water in a water-bath at $70^{\circ} \mathrm{C}$. The obtained extract was filtered and evaporated using a vacuum evaporator to give the crude dried extract (Mothana and Likdequist, 2005).

\section{Ginger extract}

Ginger rhizomes were ground and passed through a 60 mesh screen. One hundred grams of ground ginger were defatted by shaking three times with four volumes of petroleum ether in a rotary shaker for $1 \mathrm{~h}$. The residue obtained after filtration was dried overnight under a hood until all traces of petroleum ether were removed. The dried residue was extracted three times with four volumes of $90 \%$ ethanol by shaking for $1 \mathrm{~h}$. and filtered. The combined filtrate was concentrated in a rotavapor and placed under a hood to remove the residual ethanol. The obtained aqueous extract was frozen overnight and freeze-dried at $-60^{\circ} \mathrm{C}$ (Dura-Dry, USA). The freeze-dried extract was stored in airtight containers at $5^{\circ} \mathrm{C}$ until use (Mansour and khalil, 2000).

\section{Ginseng extract}

Korean red ginseng extract was obtained from the Korean Society of ginseng, Seaul, Korea by Prof Dr. Mosaad A. Abdel-Wahhab, Food Toxicology and Contamination Dept., National Research Center, Cairo, Egypt; who supplied it for us as a gift

\subsection{Determination of optimum concentration of the natural extracts}

Jojoba (Jo), jatropha (Ja), ginseng (Gg) and ginger (Gr) extracts were screened at levels ranging from 0 to $1 \%$ to determine their optimum working concentrations. Fresh lamb meat was obtained from a local slaughter house and kept overnight at $0^{\circ} \mathrm{C}$. The lamb meat was minced using a meat mincer. The four natural plant extracts were mixed with the minced lamb meat and formed into patties using a patty former. The potential antioxidants of the test extracts were determined through thiobarbituric acid reactive substances (TBARS), which were assessed in the lamb patties.
The optimum concentrations for the individual test extracts were identified during the screening trials and assessed simultaneously.

\subsection{Preparation of Lamb Patties}

Minced lamb meat was subdivided into five equal parts. Lamb patties were prepared to provide five treatment samples. A control treatment was formulated without plant extracts. The other treatments were prepared by adding the optimum concentrations determined of the tested extracts to lamb meat as follows: $0.1 \%$ jojoba (Jo) extract (sample patties with Jo), $0.1 \%$ jatropha (Ja) extract (sample patties with Ja), $0.25 \%$ ginseng (Gg) extract (sample patties with $\mathrm{Gg}$ ) and $0.25 \%$ ginger (Gr) extract (sample patties with $\mathrm{Gg}$ ); then mixed well and formed into patties $(100 \mathrm{~g})$ using a meat former. Lamb patties were placed on plastic foam meat trays, wrapped with polyethylene film and kept in a refrigerator at $4^{\circ} \mathrm{C}$ for 9 days. The effect of the optimum concentration of the test extracts on thiobarbituric acid reactive substances (TBARS), $\mathrm{pH}$, biogenic amines(BAs), mould and yeast counts \& aerobic plate count (APC) were determined in lamb patties for $0,3,6$, and 9 days of storage time at $4^{\circ} \mathrm{C}$. Hence, the patties quality and safety could be assessed.

\subsection{Chemical analyses}

\section{pH determination}

A lamb patty sample $(10 \mathrm{~g})$ was homogenized in $100 \mathrm{ml}$ distilled water for $1 \mathrm{~min}$ in a blender and the $\mathrm{pH}$ was measured using a digital $\mathrm{pH}$-meter (HAANA, HI902 meter, Germany).Two readings were taken from each of the three lamb patty samples.

\section{Thiobarbituric acid reactive substances (TBARS) value}

The TBARS values were determined spectrophotometricaly according to Byun et al., (2001). Patty samples were analyzed for the optimum concentration of each extract. Homogenized patty samples (2g) were taken and TBARS were extracted twice with $10 \mathrm{ml}$ of $0.4 \mathrm{M}$ perchloric acid. Extracts were collected and made up to $25 \mathrm{ml}$ with $0.4 \mathrm{M}$ perchloric acid and then centrifuged for $5 \mathrm{~min}$ at $1790 \mathrm{~g}$. After centrifugation, $1 \mathrm{ml}$ of extract was poured into a glass stoppered test-tube. A TBARS reagent $(5 \mathrm{ml})$ was added and the extract was heated in a boiling water bath for $35 \mathrm{~min}$. After cooling under tap-water, the absorbance of the sample was read against the appropriate blank at $538 \mathrm{~nm}$. A standard curve was prepared using 1,1,3,3 - tetraethoxypropane (TEP).

\section{Biogenic amines}

Histamine, tyramine and putrescine were extracted as follows: five grams of the sample were blended 
with $25 \mathrm{ml} 5 \%$ trichloroacetic acid. Filtration was achieved using whatman filter paper No.1. Five ml. of the extract were transferred into a suitable culture tube with $4 \mathrm{~g} \mathrm{NaCl}$ and $1 \mathrm{ml}$ of $50 \% \mathrm{Na} \mathrm{OH}$ and then shaken for $2 \mathrm{~min}$. Centrifugation were carried out for $5 \mathrm{~min}$ at $5000 \mathrm{xg}$ and the upper layer was transferred to a $50 \mathrm{ml}$ separating funnel. $15 \mathrm{ml}$ of $n$-heptane were added to the upper layer extract and extracted 3 times with $1 \mathrm{ml}$ portions of $0.2 \mathrm{~N} \mathrm{HCl}$. The extracts were collected in a glass stoppered tube and evaporated to dryness using a water bath at $95^{\circ} \mathrm{C}$ with the aid of a gentle current of air. This was followed by the formation of Dansylamines as described by Maijala and Eerola, (1993). Biogenic amine concentrations were determined according to Deabes, (2000) using the HPLC. The HPLC system was equipped with a (Waters 600) delivery system. The HPLC column was a reverse phase C18 Nucleosil column $250 \times 4 \mathrm{~mm}$, $10 \mu \mathrm{m}$ packing, (Macherey-Naggl). The detection was performed using a U.V detector (waters 486) at $254 \mathrm{~nm}$ wavelength, using a linear program of 25 min. periods and $1 \mathrm{ml} / \mathrm{min}$ constant solvent flow rate. Data were integrated and recorded using Millennium Chromatography; Manger software 2010, (Waters, Milford MA 01757)

\subsection{Microbial determinations}

\section{Aerobic plate count (APC)}

The aerobic plate count was determined on nutrient agar medium as recommended by the American Public Health Association for food stuff examination (APHA, 1992). Plates seeded with serial dilutions of the samples were incubated at $37^{\circ} \mathrm{C}$ for $24-48 \mathrm{~h}$.

\section{Mould and yeast counts}

Mould and yeast counts were estimated on Potato Agar according to APHA, (1992).The medium was acidified to $\mathrm{pH} 3.5$ by adding a sterile $10 \%$ lactic acid solution; incubation was carried out at $25-28^{\circ} \mathrm{C}$ for $72 \mathrm{~h}$.

\subsection{Statistical analysis}

The conventional statistical methods were used to calculate means and standard deviations. All the measurements were performed in triplicate and the data are presented as mean $\pm S D$. The effects of the addition of natural antioxidant extracts and storage time were analyzed and the obtained data were subjected to analysis of variance (ANOVA) according to PC-STAT, Version I A Copyright 1985, the University of Georgia.

\section{RESUTS AND DISCUSSION}

\subsection{Optimum concentration of natural plant extracts}

Based on preliminary trials, the optimum concentrations of the four tested natural plant (Jo, $\mathrm{Ja}, \mathrm{Gg}, \mathrm{Gr}$ ) extracts were incorporated into lamb patties. Potential antioxidant properties of each of the tested natural plant extracts was determined through TBARS analysis. The concentration range employed for each test extract screened was from 0 to $1.0 \%$. Doubling of the natural extracts addition rates was used in patty processing i.e. $0,0.01$, $0.05,0.10,0.25,0.50$, and $1.0 \%$ in order to have a greater effect on the assessment of the extracts' performance. Owing to the huge amount of data generated during screening; only the optimum concentrations of each of the four tested natural plant extracts are presented in Table 1. Thus, the optimum test extract addition rates based on the identified levels of antioxidant activity were determined as: jojoba $(0.1 \%)$, Jatropha $(0.1 \%)$, ginseng $(0.25 \%)$ and ginger $(0.25 \%)$.

\section{2. $\mathrm{pH}$ changes}

The effect of the optimum concentrations of natural plant extracts under investigation on the $\mathrm{pH}$ values of lamb patties stored at $4^{\circ} \mathrm{C}$ for 9 days is shown in Table 2. At zero time the $\mathrm{pH}$ of the control and all tested samples had the same value (5.92). Control samples, generally, had higher $\mathrm{pH}$ values than the other samples throughout the storage time. The $\mathrm{pH}$ values of the control and tested lamb patties containing natural antioxidant extracts were significantly $(p<0.05)$ increased gradually throughout the storage period. During storage time (3-9days) it was noticed that the $\mathrm{pH}$ value of the control samples was higher (6.29) than the other tested samples. At the $9^{\text {th }}$ day lamb

Table 1

Optimum concentration of natural plant extracts determined in Lamb patties.

\begin{tabular}{cccc}
\hline $\begin{array}{c}\text { Natural plant } \\
\text { extract }\end{array}$ & $\begin{array}{c}\text { Concentration } \\
\text { range } \\
\text { screened } \%\end{array}$ & $\begin{array}{c}\text { Optimum working } \\
\text { concentration } \\
\text { range \% }\end{array}$ & $\begin{array}{c}\text { Optimum } \\
\text { concentration } \\
\text { determined \% }\end{array}$ \\
\hline Jojoba (Jo) & $0-1$ & $0.1-0.50$ & 0.1 \\
Jatropha (Ja) & $0-1$ & $0.1-0.25$ & 0.1 \\
Ginseng (Gg) & $0-1$ & $0.25-1.00$ & 0.25 \\
Ginger $(\mathrm{Gr})$ & $0-1$ & $0.25-1.00$ & 0.25 \\
\hline
\end{tabular}


Table 2

Effect of the optimum concentration of natural plant extracts on $\mathrm{pH}$ changes and TBARS values of lamb patties stored at $4^{\circ} \mathrm{C}$ for 9 days.

\begin{tabular}{|c|c|c|c|c|}
\hline $\begin{array}{l}\text { Lamb patties } \\
\text { sample }^{*}\end{array}$ & $\begin{array}{c}\text { Day } 0 \\
M \pm S D\end{array}$ & $\begin{array}{c}\text { Day } 3 \\
M \pm S D\end{array}$ & $\begin{array}{c}\text { Day } 6 \\
M \pm S D\end{array}$ & $\begin{array}{c}\text { Day } 9 \\
M \pm S D\end{array}$ \\
\hline \multicolumn{5}{|c|}{$\mathrm{pH}$ values } \\
\hline Control & $5.92 \pm 0.00^{z}$ & $5.99 \pm 0.00 a^{y}$ & $6.16 \pm 0.00 a^{x}$ & $6.29 \pm 0.00 \mathrm{a}^{w}$ \\
\hline Jo & $5.92 \pm 0.00^{z}$ & $5.94 \pm 0.00 d^{y}$ & $5.99 \pm 0.00 e^{x}$ & $6.16 \pm 0.00 c^{w}$ \\
\hline $\mathrm{Ja}$ & $5.92 \pm 0.00^{z}$ & $5.95 \pm 0.00 c^{y}$ & $6.01 \pm 0.00 c^{x}$ & $6.14 \pm 0.00 \mathrm{~d}^{w}$ \\
\hline $\mathrm{Gg}$ & $5.92 \pm 0.00^{z}$ & $5.95 \pm 0.00 c^{y}$ & $6.00 \pm 0.00 d^{x}$ & $6.13 \pm 0.00 \mathrm{e}^{\mathrm{w}}$ \\
\hline $\mathrm{Gr}$ & $5.92 \pm 0.00^{z}$ & $5.97 \pm 0.00 b^{y}$ & $6.12 \pm 0.00 b^{x}$ & $6.19 \pm 0.00 b^{w}$ \\
\hline \multicolumn{5}{|c|}{ TBARS values (malonaldehyde $\mathrm{mg} / \mathrm{kg}$ meat) } \\
\hline Control & $0.158 \pm 0.006^{z}$ & $0.264 \pm 0.009 a^{y}$ & $0.494 \pm 0.024 \mathrm{a}^{\mathrm{x}}$ & $0.626 \pm 0.006 \mathrm{a}^{\mathrm{w}}$ \\
\hline Jo & $0.161 \pm 0.002^{z}$ & $0.174 \pm 0.004 c d^{y}$ & $0.326 \pm 0.004 b^{x}$ & $0.405 \pm 0.004 c^{w}$ \\
\hline $\mathrm{Ja}$ & $0.161 \pm 0.002^{z}$ & $0.174 \pm 0.004 c d^{y}$ & $0.324 \pm 0.004 c^{x}$ & $0.404 \pm 0.001 c^{w}$ \\
\hline $\mathrm{Gg}$ & $0.160 \pm 0.003^{z}$ & $0.165 \pm 0.005 d^{y}$ & $0.304 \pm 0.004 c^{x}$ & $0.393 \pm 0.003 d^{w}$ \\
\hline $\mathrm{Gr}$ & $0.161 \pm 0.003^{z}$ & $0.185 \pm 0.009 b^{y}$ & $0.345 \pm 0.004 b^{x}$ & $0.436 \pm 0.004 b^{w}$ \\
\hline
\end{tabular}

${ }^{*} \mathrm{Jo}=$ patties with jojoba extract. Ja = patties with jatropha extract. $\mathrm{Gg}=$ patties with ginseng extract. Gg $=$ patties with ginger extract. Control = patties without any extract. $\mathrm{M} \pm \mathrm{SD}=$ Mean \pm Standard Deviation.

*Letters a-e to show significant differences $(P<0.05)$ between the same column. Letters $\mathrm{w}$ - $\mathrm{z}$ to show significant differences $(P<0.05)$ between rows.

patties containing ginger extract (sample $\mathrm{Gr}$ ) had the highest $\mathrm{pH}$ value and patties containing ginseng extract (sample Gg) had of the lowest value. Similar findings in pork patties and in ground buffalo meat containing BHA/BHT antioxidants during refrigerated and frozen storage, respectively have been reported by (McCarthy et al., 2001; Sahoo, 1995). The increase in $\mathrm{pH}$ may be due to the accumulation of metabolites by bacterial action in meat and deaminations of proteins (Jay, 1996). Bacteria, upon exhaustion of stored glucose, utilize amino acids released during protein breakdown and, as a product of amino acid degradation, ammonia accumulates and $\mathrm{pH}$ rises (Gill, 1983).

\subsection{Thiobarbituric acid reactive substances (TBARS)}

The data presented in Table 2 show the changes of TBARS values in the lamb patties containing optimum concentrations of the tested natural extracts stored at $4^{\circ} \mathrm{C}$ for 9 days. The screened natural extracts were effective as antioxidants and had lower TBARS values than the control samples throughout the storage period. The effectiveness of the added natural plant extracts as antioxidants inhibiting lipid oxidation throughout storage time could be listed in the following order of decreasing TBARS values: Ginseng > jatropha $>$ jojoba $>$ ginger. Results also show that the ginseng extract was the most effective antioxidant and ginger had the lowest effect. This can indicate that the optimum concentration of the natural plants used as antioxidants was effective against TBARS formation in a different way when incorporated into lamb patties. Estevez et al., (2004); Formanek et al., (2001); McCarthy et al., (2001); Chen et al., (1999), reported that dried herbs and their essential oils were successfully used to reduce lipid oxidation in meat products. Polyphenolic extracts are excellent electron and proton donors, and their intermediate radicals are quite stable due to electron delocalization phenomena and owing to the lack of positions attackable by $\mathrm{O}_{2}$ (Djenane et al., 2005). In the present study, since the natural extracts used in preparing lamb patties contain bioactive substances e.g. phenolic compounds in Jatropha and ginger (El-Diwani et al., 2009; Stoilova et al., 2007), flavonoids in jojoba (El-Halawany, 2002) and tritpenes saponins in ginseng (Fuzzati, 2004); these substances could cause an inhibition of the chain reactions during lipid oxidation.

\subsection{Microbial changes}

Meat is prone to both microbial and oxidative spoilage and therefore it is important to use a preservative with both antioxidant and antimicrobial properties (Kanatt et al., 2008). The growing concern about the safety of foods has led to the development of natural antimicrobials to control food-borne pathogen (Nevas et al., 2004).

\section{Aerobic plate count (APC)}

Table 3 shows the effect of adding optimum concentrations of the natural plant extracts to the prepared lamb patties stored at $4^{\circ} \mathrm{C}$ for 9 days on 
Table 3

Changes in Aerobic plate count, mould and yeast counts of lamb patties stored at $4^{\circ} \mathrm{C}$ for 9 days.

\begin{tabular}{|c|c|c|c|c|}
\hline \multirow{2}{*}{$\begin{array}{l}\text { Lamb patties } \\
\text { sample* }^{*}\end{array}$} & Day 0 & Day 3 & Day 6 & Day 9 \\
\hline & $M \pm S D$ & $\mathbf{M} \pm \mathbf{S D}$ & $\mathbf{M} \pm \mathbf{S D}$ & $\mathbf{M} \pm \mathrm{SD}$ \\
\hline \multicolumn{5}{|c|}{ Aerobic plate count (Log CFU/g) } \\
\hline Control & $4.06 \pm 0.019^{z}$ & $4.99 \pm 0.012 a^{y}$ & $6.23 \pm 0.010 a^{x}$ & $7.57 \pm 0.027 a^{w}$ \\
\hline Jo & $4.06 \pm 0.019^{z}$ & $4.17 \pm 0.050 c^{y}$ & $4.30 \pm 0.019 c^{x}$ & $4.94 \pm 0.040 \mathrm{~b}^{\mathrm{w}}$ \\
\hline $\mathrm{Ja}$ & $4.06 \pm 0.019^{z}$ & $4.18 \pm 0.064 c^{y}$ & $4.30 \pm 0.031 c^{x}$ & $4.96 \pm 0.021 b^{w}$ \\
\hline $\mathrm{Gg}$ & $4.06 \pm 0.019^{y}$ & $4.10 \pm 0.009 d^{y}$ & $4.18 \pm 0.019 d^{x}$ & $4.82 \pm 0.035 b^{w}$ \\
\hline $\mathrm{Gr}$ & $4.06 \pm 0.019^{y}$ & $4.26 \pm 0.009 b^{x}$ & $4.45 \pm 0.035 b^{x}$ & $4.84 \pm 0.312 b^{w}$ \\
\hline \multicolumn{5}{|c|}{ Mould and yeast counts (Log CFU /g) } \\
\hline Control & $2.32 \pm 0.019^{z}$ & $2.88 \pm 0.015 a^{y}$ & $3.22 \pm 0.015 a^{x}$ & $3.66 \pm 0.015 a^{w}$ \\
\hline Jo & $2.32 \pm 0.019^{z}$ & $2.43 \pm 0.047 c^{y}$ & $2.52 \pm 0.025^{x}$ & $2.59 \pm 0.009 c^{w}$ \\
\hline $\mathrm{Ja}$ & $2.32 \pm 0.019^{y}$ & $2.42 \pm 0.058 c^{x}$ & $2.53 \pm 015 c^{w}$ & $2.59 \pm 0.021 c^{w}$ \\
\hline $\mathrm{Gg}$ & $2.32 \pm 0.019^{y}$ & $2.35 \pm 0.045 d^{y}$ & $2.43 \pm 0.019^{x}$ & $2.51 \pm 0.020 d^{w}$ \\
\hline $\mathrm{Gr}$ & $2.32 \pm 0.019^{z}$ & $2.50 \pm 0.010 b^{y}$ & $2.60 \pm 0.021^{x}$ & $2.79 \pm 0.029 b^{w}$ \\
\hline
\end{tabular}

${ }^{*} \mathrm{Jo}=$ patties with jojoba extract. Ja = patties with jatropha extract. $\mathrm{Gg}=$ patties with ginseng extract. Gg = patties with ginger extract. Control $=$ patties without any extract. $\mathrm{M} \pm \mathrm{SD}=$ Mean \pm Standard Deviation. * Letters a-e to show significant differences $(P<0.05)$ between column. Letters $w$ - $z$ to show significant differences $(P<0.05)$ between rows.

aerobic plate count (APC). A remarkable increase was noticed in APC throughout storage, especially in the control sample at days 6 and 9 (from 6.23 to $7.57 \mathrm{Log}$ CFU/g) respectively. It has been reported by Insausti et al., (2001) that meat spoilage cannot be said to occur until Total Vaiable Count (TVC) counts reach $10^{6}-10^{8} \mathrm{CFU} \mathrm{g}^{-1}$ (limit of microbiological acceptability). In general, a significant decrease was noticed for all tested patty samples in their aerobic plate count during the storage period (3-9 days). Worth noting is the fact that sample $\mathrm{Gg}$ (containing ginseng extract) was of the lowest APC and the patties with ginger extract (sample $\mathrm{Gr}$ ) had the highest compared the other samples. Thus, the results show that the aerobic plate count (APC) decreased significantly with the addition of the natural extracts during storage at $4^{\circ} \mathrm{C}$ for 9 days. Igbinosa et al., (2009) concluded that Jatropha curcas stem bark could be a potential source of active antimicrobial agents. Also, Jitoe et al., (1992); Zia-ur-Rehman et al., (2003) found that ginger has antioxidant activity and effective antimicrobial agents.

\section{Mould and yeast counts}

Mould and yeast counts of the prepared lamb patties containing the optimum concentrations of the tested natural extracts during storage for 9 days at $4^{\circ} \mathrm{C}$ are given in Table 3. It was observed that both the addition of the natural extracts and the storage time had a significant effect on the mould and yeast counts. The control samples had the highest mould and yeast counts throughout the storage period. In general, the patty samples containing the natural extracts Jo, Ja, Gg and Gr increased in their mould and yeast counts at the end of storage period.
Lamb patties containing ginger extract (sample Gr) were noticed to be of high mould and yeast counts. A higher reduction in mould and yeast counts was observed in the patties containing ginseng extract (sample Gg) than in samples Jo, Ja and Gr during the storage time. Meanwhile, samples containing jojoba and Jatropha (Jo and Ja) were of nearly the same mould and yeast counts. Thus, addition of the tested natural extracts reduced the mould and yeast counts in the prepared lamb patties. Spices and herbs used in food stuffs for enhancing flavor or color attributes, generally have antimicrobial as well as antioxidant activities (Baydar et el., 2004; Sağdic and Ǒzcan 2003; Yanishlieva and Marinova 2001). The addition of ginseng extract was found to be more effective in reducing APC and mould \& yeast counts in the tested lamb patties.

\subsection{Biogenic Amines (BAs)}

The production of biogenic amines during the storage or processing of food products is an extremely complex phenomenon depending on several variables, such as the growth of microorganisms, several extrinsic and intrinsic factors during the manufacturing process such as formulation, some physico-chemical parameters and proteolytic \& decarboxylase activities which interact with each other (Latorre-Moratalla et al., 2008; Suzzi and Gardini, 2003).

Table 4 shows the effect of adding optimum concentrations of natural extracts to the prepared lamb patties stored at $4^{\circ} \mathrm{C}$ for 9 days on the formation of biogenic amines. Histamine, tyramine and putrescine $(\mathrm{mg} / \mathrm{kg})$ were not detected in lamb patties at zero time of storage. It was observed that storage time had a significant effect $(p<0.05)$ 
Table 4

Effect of the optimum concentration of natural plant extracts on concentration of biogenicamines in lamb patties stored at $4^{\circ} \mathrm{C}$ for 9 days.

\begin{tabular}{|c|c|c|c|c|}
\hline \multirow{2}{*}{$\begin{array}{c}\text { Lamb patties } \\
\text { samples* }\end{array}$} & Day 0 & Day 3 & Day 6 & Day 9 \\
\hline & $M \pm S D$ & $\mathbf{M} \pm \mathbf{S D}$ & $M \pm S D$ & $M \pm S D$ \\
\hline \multicolumn{5}{|c|}{ Histamine concentration $(\mathrm{mg} / \mathrm{kg})$} \\
\hline Control & ND & $4.26 \pm 0.187 a^{y}$ & $6.84 \pm 0.127 a^{x}$ & $11.04 \pm 0.147 a^{w}$ \\
\hline Jo & ND & $2.89 \pm 0.100 b c^{y}$ & $4.03 \pm 0.057 c^{x}$ & $6.36 \pm 0.138 c^{w}$ \\
\hline $\mathrm{Ja}$ & ND & $2.90 \pm 0.089 b c^{y}$ & $3.98 \pm 0.068 c d^{x}$ & $6.36 \pm 0.100 c^{w}$ \\
\hline $\mathrm{Gg}$ & ND & $2.67 \pm 0.318 c^{y}$ & $3.74 \pm 0.25 d^{x}$ & $6.10 \pm 0.163 d^{w}$ \\
\hline $\mathrm{Gr}$ & ND & $3.14 \pm 0.136 b^{y}$ & $4.35 \pm 0.125 b^{x}$ & $7.04 \pm 0.064 b^{w}$ \\
\hline \multicolumn{5}{|c|}{ Tyramine concentration (mg/kg) } \\
\hline Control & ND & $5.38 \pm 0.170 a^{y}$ & $7.84 \pm 0.140 \mathrm{a}^{\mathrm{x}}$ & $13.34 \pm 0.555 \mathrm{a}^{\mathrm{w}}$ \\
\hline Jo & ND & $3.94 \pm 0.055 c d^{y}$ & $5.89 \pm 0.061 c d^{x}$ & $8.04 \pm 0.074 c^{w}$ \\
\hline $\mathrm{Ja}$ & ND & $4.02 \pm 0.031 c^{y}$ & $5.95 \pm 0.045 b c^{x}$ & $8.10 \pm 0.119 c^{w}$ \\
\hline $\mathrm{Gg}$ & ND & $3.72 \pm 0.076 d^{y}$ & $5.68 \pm 0.252 d^{x}$ & $7.43 \pm 0.130 d^{w}$ \\
\hline $\mathrm{Gr}$ & ND & $4.46 \pm 0.201 b^{y}$ & $6.15 \pm 0.130 \mathrm{~b}^{\mathrm{x}}$ & $8.85 \pm 0.127 b^{w}$ \\
\hline \multicolumn{5}{|c|}{ Putrescine concentration ( $\mathrm{mg} / \mathrm{kg})$} \\
\hline Control & ND & $6.14 \pm 0.085 a^{y}$ & $8.22 \pm 0.157 a^{x}$ & $12.58 \pm 0.407 a^{w}$ \\
\hline Jo & ND & $4.16 \pm 0.115 c^{y}$ & $5.53 \pm 0.231 c^{x}$ & $7.90 \pm 0.096 c^{w}$ \\
\hline $\mathrm{Ja}$ & ND & $4.18 \pm 0.095 c^{y}$ & $5.54 \pm 0.216 c^{x}$ & $8.06 \pm 0.081 c^{w}$ \\
\hline $\mathrm{Gg}$ & ND & $3.42 \pm 0.126 d^{y}$ & $4.81 \pm 0.165 d^{x}$ & $6.40 \pm 0.180 d^{w}$ \\
\hline $\mathrm{Gr}$ & ND & $4.45 \pm 0.065 b^{y}$ & $6.25 \pm 0.122 b^{x}$ & $8.84 \pm 0.140 b^{w}$ \\
\hline
\end{tabular}

*Jo $=$ patties with jojoba extract. Ja = patties with jatropha extract. Gg = patties with ginseng extract. Gg = patties with ginger extract. Control $=$ patties without any extract. $\mathrm{ND}=$ none detected. $\mathrm{M} \pm \mathrm{SD}=$ Mean \pm Standard Deviation. Letters a-e to show significant differences $(P<0.05)$ between column. Letters $w-z$ to show significant differences $(P<0.05)$ between rows.

for up to 9 days at $4^{\circ} \mathrm{C}$ on the formation of all the estimated biogenic amines.

Histamine concentrations varied from 4.26 to $11.04 \mathrm{mg} / \mathrm{kg}$ in the control sample during storage at $4^{\circ} \mathrm{C}$ for 9 days. Data in Table 4 show that on 3 , 6 and 9 days histamine concentrations of all lamb patty samples were significantly $(p<0.05)$ increased gradually. All natural plant extracts were effective in producing lower histamine concentrations than control samples over the storage period. Results show that ginseng extract was the most effective, while ginger was the least effective. Meanwhile, jatropha and jojoba extracts were nearly equal in their effectiveness against histamine formation.

The permitted level of tyramine in foods is 100$800 \mathrm{mg} / \mathrm{kg}$, while $1080 \mathrm{mg} / \mathrm{kg}$ is toxic (Shalaby, 1996). Tyramine concentrations, in the present study, were found in the safe range and lower than the permitted level. They varied in the control patty sample from 3.72 to $13.34 \mathrm{mg} / \mathrm{kg}$ during the 3-9 days of storage at $4^{\circ} \mathrm{C}$ (Table 4$)$. The tyramine contents in the patties containing the tested extracts were still less than the control level at day 9 . Using the tested natural antioxidants was found to significantly reduce $(P<0.05)$ tyramine formation. The reduction of tyramine in lamb patty samples with Jo, Ja, Gg and Gr relative to the control sample was about $39.8 \%$ for jojoba, $39.4 \%$ for jatropha,
$54.4 \%$ for ginseng and $33.7 \%$ for ginger extracts at the end of the storage period. Storage time had a significant effect $(p<0.05)$ on tyramine formation, its concentrations in the tested patties samples increased significantly during the storage period and at day 9 reached $8.04,8.10,7.43$ and $8.85 \mathrm{mg} /$ $\mathrm{kg}$ in the four lamb patty samples Jo, Ja, Gg and $\mathrm{Gr}$ respectively. The ginseng extract showed the lowesttyramine content $7.43 \mathrm{mg} / \mathrm{kg}$ thus presenting a marked effect on this BA formation. Eerola et al., (1997) observed that tyramine concentration in sausages increased during 7 days of storage at $4^{\circ} \mathrm{C}$. The reduction in tyramine formation through natural antioxidant extracts is important with respect to human health because tyramine causes migraine headaches, increased blood pressure and an increase in noradrenalin as has been previously reported by Ruiz-Capillas and Jiminez-Colmenero, (2004).

The addition of the tested plant extracts in the preparation of the lamb patties stored at $4^{\circ} \mathrm{C}$ for 9 days significantly affected $(p<0.05)$ the formation of putrescine. Its concentration increased up to 12.58, 7.90, 8.06, 6.40 and $8.84 \mathrm{gm} / \mathrm{kg}$ in the control and patty samples containing Jo, Ja, Gg and $\mathrm{Gr}$ respectively at the end of the storage period (Table 4). The highest putrescine concentration was observed in the control sample; while the 
lowest was for sample $\mathrm{Gg}$ containing the ginseng extract. Thus, the addition of natural plant extracts was found to be effective in reducing the formation of putrescine. The ranking in decreasing order of effectiveness of the applied extracts on putrescine concentration in the lamb patty samples is: ginseng $>$ jojoba $>$ jatropha $>$ ginger. This reduction could also be due to the antimicrobial activities of the natural extracts. Putrescine formation depends on the total aerobic count where a high total aerobic count results in high putresine formation (RuizCapillas and Jiminez-Colmenero, 2004).

Therefore, it can be stated that the addition of optimum concentration of the used natural plant extracts to lamb patties resulted in a marked significant reduction in histamine, tyramine and putrescine formation.

\section{CONCLUSION}

Comparison of control and treated lamb patty samples during storage at $4^{\circ} \mathrm{C}$ for 9 days showed that the addition of the investigated natural plant extracts was effective as antioxidant and anti microbial agents for improving the properties of the prepared lamb patties from a quality and safety view point. The results show that, in general, the ginseng extract was the most effective while the ginger extract was the least. Also, It was noticed that the optimum concentration of the investigated natural extracts were effective in reducing the aerobic plate count (APC), mould \& yeast counts and against the formation of biogenic amines (histamine, tyramine and putrescine) as well as reducing TBARS; although their performance differed when incorporated into lamb patties. The effectiveness of the tested natural antioxidant extracts could be listed in the following order of decreasing TBARS value: Ginseng $>$ jatropha $>$ jojoba $>$ ginger.

\section{REFRENCES}

Alma MH, Mavi A, Yildirim A, Digrak M, Hirata T. 2003. Screening chemical composition and in vitro antioxidant and antimicrobial activities of the essential oils from Origanum syriacum growing in Turkey. Biol Pharm Bull 26, 1725-29

APHA (American Public Health Association). 1992. Compendium Methods for the Microbiological Examination for Foods pp.75-97, 239-250 and 325-420 APHA, Washington, D.C. U.S.A.

Azaizeh H, Ljubuncic P, Portnaya I, Said O, Cogan U, Bomzon A. 2005. Fertilization-induced changes in growth parameters and antioxidant activity of medicinal plants used in traditional Arab medicine. Evid Based Complement Alternat Med. 2, 549-56.

Baydar H, Sagdic O, Gulcan O, karadogan T. 2004. Antibacterial activity and composition of essential oils from Origanum, Thymbra, an Satureja species with commercial importance in Turkey. Food Control 15, 169-172

Bozin B, Mimica-Dukic N, Samojlik I, Jovin EA. 2007. Antimicrobial and antioxidant properties of rosemary and sage (Rosmarinus officinal is $L$. and salvia officinalis $L$., Lamiaceae) essential oils. J Agric Food 55, 7879-7885

Byun MW, Lee JW, Jo C, Yook HS.2001. Quality properties of sausage made with gamma-irradiated natural pork and lamb casing. Meat Sci 59, 223-228.

Camo J, Beltran JA, Roncales P. 2008. Extension of the display life of lamb with an antioxidant active packaging. Meat Sci 80, 1086-1091

Chen X, Jo C, Lee JI, Ahn DU. 1999. Lipid oxidation, volatiles and color changes of irradiated pork patties as affected by antioxidants. J Food Sci 64, 16 -19

Deabes MMY. 2000. Studies on some biogenic amines in some meat and fish products with respect to other quality attributes. M.Sc. Thesis, Food Science \&Technology Dept., Faculty of Agriculture, Al-Azhar Univr., Cairo, Egypt.

Djenane D, Montañés L, Roncalés P. 2005. Nuevas perspectivas para la conservación natural de la carne. Eurocarne 133, 153-180.

Eerola S, Sagues AXR, Lilleberg L, Aalto H. 1997. Biogenic amines in dry sausage during shelf-life storage. Zeitunig Lebensmittel Fur Unters Forsch. A 205, 351-55

El Diwani G, El Rafie S, Hawash S. 2009. Protection of biodiesel and oil from degradation by natural antioxidants of Egyptian Jatropha. Int. J. Environ. Sci. Tech. 6 (3), $369-378$

El-Halawany AMA. 2002. Pharmacognostical study of Simmondsia Chinenisis (Link) Schneider family Buxaceae (Simmondsiaceae) cultivated in Egypt. M.Sc, Thesis Pharmaceutical Science (pharmacognosy), Pharmacognosy Department, Faculty of Pharmacy, Cairo University

Estevez M, Cava R. 2006. Effectiveness of rosemary essential oil as an inhibitor of lipid and protein oxidation: Contradictory effects in different types of frankfurters. Meat Sci. 72, 348-355.

Estevez M, Morcuende D, Ventanas J, Cava R. 2004. Effect of the addition of sage and rosemary extracts on the oxidative stability of different types of liver pates. In proceedings of 50th ICOMST pp.194-195, Helsinki, Finland.

Formanek Z, Kerry JP, Higgins FM, Buckley DJ, Morrissey P A, Farkas J. 2001. Addition of synthetic and natural antioxidants to $\alpha$-tocopheryl acetate supplemented beef patties: Effects of antioxidants and packaging on lipid oxidation. Meat Sci. 58, 337-341.

Fuzzati N. (2004). Analysis methods of ginsenosides. Journal of Chromtography B, 812,119 -133.

Gillis CN. 1997. Panax ginseng Pharmacology. A Nitric Oxide Link?. Biochem. Pharmacol. 54, 1-8.

Gill CO, 1983. Meat spoilage and evaluation of the potential storage life of fresh meat. J. Food Prot. 46, 444-452.

Gray JJ, Gomaa EA, Buckley DJ. 1996. Oxidative quality and shelf life of meats. Meat Sci. 43, 111-23

Gubitz GM, Mittlebeach M, Trabi M.1999. Exploitation of tropical oil seed plant Jatropha curcas L. Biosource Techol. 67 (1), 73-82.

Hawash S, Kamal N, Zaher F, Kenawi O, El Diwani G. 2009. Biodiesel fuel from Jatropha oil via noncatalytic supercritical methanol transesterification. Fuel 88, 579-582.

Igbinosa OO, Igbinosa EO, Aiyegoro OA. 2009. Antimicrobial activity and phytochemical screening of stem bark extracts from Jatropha curcas (Linn). Afr. J. Pharm. Pharmacol. 3, 58-62.

Insausti K, Beriain MJ, Purroy A, Alberti P, Gorraiz C, Alzueta C, Alzueta M J. 2001. Shelf life of beef from 
local Spanish cattle breed stored under modified atmosphere. Meat Sci. 57, 273-281.

Jay JM.1996. Antioxidants. In: Modern food microbiology (4 ${ }^{\text {th }}$ Ed.).CBS Publishers and Distributors, pp. 265266 New Delhi, India

Jeremiah LE. 2001. Packaging alternatives to deliver fresh meats using short-or long-term distribution. Food Res. Int. 34, 749-772.

Jitoe A, Masuda T, Tengah IP, Suprapta DN, Gara I W, Nakatan N.1992. Antioxidant activity of tropical ginger extract and analysis of the contained curcuminoids. $J$. Agric. Food Chem. 40, 1337-1340.

Joyeux M, Moitier F, Fleurentin J.1995. Screening of antiradical, antilipo- peroxidant and hepatoprotective effects of nine plant extracts used in caribbean folk medicine. Phytother Res. 9, 228-30

Kanatt RS, Chander R, Sharma A. 2008. Chitosan and mint mixture: A new preservative for meat and meat products. Food Chemistry 107, 845-852.

Kikuzaki H, Nakatani N.1993. Antioxidant effects of some ginger constituents. J. Food Sci. 58, 1407-1410.

Lai SM, Gray JI, Smith DM, Booren AM, Crackel RL, Buckley DJ. 1991. Effects of oleoresin rosemary, Tertiary butyl-hydroquinone and sodium tripolyphosphate on the development of oxidative rancidity in restructured chicken nuggets. J. Food Sci. 56,616-620.

Latorre-Moratalla ML, Veciana-Nogués T, Bover-Cid $S$, Garriga M, Aymerich T, Zanardi E, lanieri A, Fraqueza MJ, Patarata L, Drosinos EH, Laukova A, Talon R, Vidal-Carou MC. 2008. Biogenic amine in traditional fermented sausage produced in selected European countries. Food Chem. 107, 912-921.

Lee TG, Williams SK, Sloan D, Littell R. 1997. Development and evaluation of a chicken breakfast sausage manufactured with mechanically debond chicken meat. Poultry Sci. 76, 415-21.

Maijala RL, Eerola SH.1993. Contaminant Lactic acid bacteria of dry sausage produced histamine and tyramine. Meat Sci. 35, 387-395.

Makkar HPS, Beaker K, Sporer F, Wink M. 1997. Studies on nutritive potential and toxic constituents of different provenances of Jatropha curcas. J. Agr. Food Chem. 45, 3152-3157.

Mansour EH, Khalil AH. 2000. Evaluation of antioxidant activity of some plant extracts and their application to ground beef patties. Food Chem. 69, 135-141.

McCarthy TL, Kerry JP, Kerry JF, Lynch PB, Buckley DJ. 2001. Evaluation of the antioxidant potential of natural food/plant extracts as compared with synthetic antioxidants and vitamin $E$ in raw and cooked pork patties. Meat Sci. 57, 45-52.

Mielnik MB, Abby K, Skrede G. 2003. Synthetic antioxidants control lipid oxidation in mechanically deboned turkey meat. Meat Sci. 65, 1147-55.

Mielnik MB, Signe S, Bjorg E, Grete S. 2008. By-products from herbs essential oil production as ingredient in marinade for turkey thighs. Food Sci. Technol. 41, 93100.

Mothana RAA, Likdequist U. 2005. Antimicrobial activity of some medicinal plants of island Soqotra. Journal of Ethanopharmcology 96, 177-181.

Nevas M, Korhonen AR, Lindrom M, Turkki P, Korkeala H. 2004. Antibacterial efficiency of finnish spices essential oils against pathogenic and spoilage bacteria. J. Food Prot. 67, 199-202.

Nissen LR, Byrne DV, Bertelsen G, Skibsted LH. 2004. The antioxidative activity of plant extracts in cooked pork patties as evaluated by descriptive sensory profiling and chemical analysis. Meat Sci. 68, 485-495.
Oladele PE, Oshodi AA.2007. Nutritional potential of berlandier nettle spurge (jatropha catharetica) seed. Pakistan Journal of Nutrition 6, 345-348.

Önal A. 2007. A review: Current analytical methods for the determination of biogenic amines in foods. Food Chem. 103, 1475-1486.

PC-STAT, Version I A Copyright 1985, the University of Georgia.

Rangahau MK. 2001. Ginseng. Crop \& Food Research [Broad sheet] New Zealand Institute for Crop \& Food Research Ltd, A crown Research Institute.

Reddy V, Urooj A, Kumar A. 2005. Evaluation of antioxidant activity of some plant extracts and their application in biscuits. Food Chem. 90, 317-321.

Ruiz-Capillas C, Jimenez-Colmenero F. 2004. Biogenic amines in meat and meat products. Crit. Rev. Food Sci. Nutr. 44, 489-499.

Sağdiç O, Özcan M. 2002. Antibacterial activity of Turkish spice hydrolysis. Food Control 14,141-143.

Sahoo J. 1995. Effect of preblending and vacuum packaging on the quality of ground buffalo meat. Ph.D. Thesis submitted to Deemed University, IVRI, Izatnagar, India.

Sallam KHI, Ishioroshi M, Samejim K. 2004. Antioxidant and antimicrobial effects of garlic in chicken sausage. Lebensm. Wiss Technol. 37, 849-55.

Shalaby AR.1997. Significance of biogenic amines to food safety and human health. Food Res. Int. 29, 675-690.

Shen XH, Ren YP, Chen Y. 2003. Detection of ginsenoside in health foods by HPLC. Chinese Journal of Health Laboratory Technology 5, 600-601.

Sievenpiper JL, Arnason JT, Leiter LA, Vuksan V. 2003. Variable effects of American ginseng: a batch of American ginseng (Panax quinquefolius L.) with a depressed ginsenoside profile does not effect postprandial glycemia. European Journal of Clinical Nutrition and Metabolism 57, 243-248.

Solomakos N, Govaris A, Koidis P, Botsoglous N. 2008. The antimicrobial effect of thyme essential oil, nisin, and their combination against Listria mono cyto genes in minced beef during refrigerated storage. Food Microbiol. 25, 120-127.

Stoilova I, Krastanov A, Stoyanova A, Denev P, Gargova S. 2007. Antioxidant activity of a ginger extract (Zingiber officinale). Food Chem. 102, 764-770.

Suzzi G, Gardini F. 2003. Biogenic amines in dry fermented sausages: a review. Int J Food Microbiol. 88, 41-54.

Tang S, Kerr JP, Sheehan D, Buckley DJ, Morrissey PA 2001. Antioxidative effect of added tea catechins on susceptibility of cooked red meat, poultry and fish patties to lipid oxidation. Food Res. Int. 34, 651-657.

Teague, Richard King (Edenton, NC); Tynch; Samuel Leonard (Edenton, NC); Jaksch, Jr.; Frank Louis (Irvine, CA); Maier, Jr.; Richard Theodore (Hertford, NC). "Compounds for altering food intake in humans", United States Patent: 6,852,342; Issued: February 8 (2005), Avoca, Inc. (Merryhill, NC); ChromaDex, Inc. (Santa Ana, CA), Appl. No.: 108036.

Willcox JK, Ash SL, Catignani GL. 2004. Antioxidants and prevention of chronic diseases. Crit. Rev. Food Sci. Nutr. 44, 275-95.

Wood JD, Enser M, Fisher AV, Nute GR, Richardson RI, Sheard PR. 1999. Manipulating meat quality and composition. In: Proceedings of the nutrition society, Vol. 58: (pp. 363-370) 29 June-2 July 29, Surrey, England. 
Yanishlieva NV, Marinova EM. 2001. Stabilization of edible oils with natural antioxidant. Eur. J. Lipid Sci. Technol. 103, 752-767.

Yanishlievaa NV, Marinova E, Pokorny J. 2006. Natural antioxidants from herbs and spices. Eur. J. Lipid Sci. Technol. 108, 776-79.
Zia-ur-Rehman S, Salariya AM, Habib F.2003. Antioxidant activity of ginger extract in sunflower oil. J. Sci. Food Agric. 83, 624-629.

Recibido: $7 / 6 / 10$ Aceptado: 24/8/10 